\title{
Preparation of spray dried low heat powder from mare's milk. Evolution on storage
}

\author{
P Schuck, A Pierre \\ Laboratoire de recherches de technologie laitière, INRA, 65, rue de Saint-Brieuc, \\ 35042 Rennes cedex, France
}

(Received 8 February 1995; accepted 22 May 1995)

\begin{abstract}
Summary - A high quality milk powder was obtained by spray drying after concentration of mare's milk by vacuum evaporation. Few alterations of milk constituents were noted. Physical characteristics were high: solubility index $>99.5 \%$; dispersibility index $>97.0 \%$; wettability index $<5 \mathrm{~s}$. Bacterial count at $30^{\circ} \mathrm{C}$ was as low as $400 \mathrm{cfu} / \mathrm{g}$. Despite the high hygroscopicity, these properties were not altered during a 3-month storage at ambient temperature.
\end{abstract}

mare's milk / low heat powder / storage

Résumé - Préparation de poudre de lait de jument et qualité de conservation. Le séchage par atomisation d'un concentré de lait de jument obtenu par évaporation sous vide permet l'obtention d'une poudre d'excellente qualité chimique (absence d'altérations des constituants du lait ; norme low heat), physique (indice de solubilité $>99,5 \%$; indice de dispersibilité $>97,0 \%$ et indice de mouillabilité < 5 s) et microbiologique (flore bactérienne mésophile : $400 \mathrm{ufc/g}$ ). Le stockage de cette poudre pendant trois mois n'a pas altéré ses propriétés, malgré sa forte hygroscopicité.

lait de jument / poudre low heat / conservation

\section{INTRODUCTION}

Since 1980 , horse breeding has been expanding in France, due to the current evolution of the agricultural production systems (Baudoin, 1990; Langlois et al, 1994). Breeders supply animals for leisure needs and for butchery; however, they are also searching for complementary high added value revenue of their herds, and mare's consumption milk could be an opportunity. Mare's milk was traditionally produced in eastern Europe and in Asia for nutritional or dietetic uses (Doreau, 1991). Thus, adjustment of a technological process in this view will be of great interest. 
Nevertheless, mare's milk collection is already optimized and milking machines are operating in France in experimental farms (Le Du, 1986). Milk preservation has been, until now, achieved by freezing and subsequent storage at $-20^{\circ} \mathrm{C}$. Such a storage process has some disadvantages, regarding the quality of the product (development of fat oxidation leading to flavor defects, milk gelation on thawing), the lack of flexibility for retail sale and the cost of the storage in a frozen state. Feasibility of mare's milk spray drying was investigated in this study. The knowledge obtained for cow's milk spray drying will be used as the starting point to realize mare's milk treatment. Adaptation of working parameters generally used for spray drying cow's milk was necessarily due to the high differences in the composition of both milks, particularly the lactose level and the protein/lactose ratio. Spray dried low heat powder was prepared from mare's milk and evolution of its quality on storage was tested. This paper describes the chemical, physical and microbiological characterization of spray dried low heat powder from mare's milk. Studies were based on those previously carried out for cow's milk powder technology.

\section{MATERIALS AND METHODS}

Mare's milk was provided by LEPA (Lycée d'Enseignement Professionnel Agricole, Semur-enAuxois, France). Milk was collected from 12 mares of "Auxois" breed over a whole lactation period. The bulk milk (500 I) was gathered after milking in $30 \mathrm{I}$ containers frozen and stored at $-20^{\circ} \mathrm{C}$ for 9 months until experimentation. Then, it was first thawed at $2^{\circ} \mathrm{C}$ for $3 \mathrm{~d}$ and defatted at $50^{\circ} \mathrm{C}$ on a cream separator (MM1254D Westfalia, Chateau Thierry, France). Concentration of milk was performed in a 2-stage falling film vacuum evaporation pilot plant (Laguilhare, Rueil-Malmaison, France) at Bionov (Rennes, France). The first evaporation stage temperature was carried out at $60^{\circ} \mathrm{C}$ and led to a concentrated milk temperature of $38^{\circ} \mathrm{C}$. Evaporation capacity was $180 \mathrm{~kg}$ $\mathrm{h}^{-1}$. Spray drying of the concentrated milk was realized at Bionov (Rennes, France), in a in 3 stages pilot plant spray drier, (Niro Atomizer, Rueil Malmaison, France). This atomizer was equipped with a pressure nozzle $(0.73 \mathrm{~mm}$ orifice diameter) and a 4 -slot core $(0.51 \mathrm{~mm}$ nominal width), leading to a $60^{\circ}$ sprayer angle. The evaporation capacity was 70 to $120 \mathrm{~kg} \mathrm{~h}^{-1}$. The pressure nozzle was at $16 \mathrm{MPa}$. Inlet air temperature was at $273-280^{\circ} \mathrm{C}$, integrated fluid bed air temperature was at $90^{\circ} \mathrm{C}$ and outlet air temperature was at $100^{\circ} \mathrm{C}$

Chemical analysis of liquid milk and of milk powder involved the following: total solids (TS) on a 5-g sample mixed with sand and maintained in a dry oven $\left(105^{\circ} \mathrm{C}\right)$ for $7 \mathrm{~h}$; nitrogen fractions according to Rowland (1938): noncasein nitrogen (NCN), nonprotein nitrogen (NPN) and total nitrogen $(T N)$, from which were calculated $(\times 6.38)$ the corresponding protein levels. The isoionic point of casein in mare's milk had been determined in preliminary experiments. It was $\mathrm{pH} 4.6$, as in cow's milk. Thus, NCN separation was maintained without modification of the original method. The soluble whey protein index (SWPi) was calculated as: TN-NCN/TN. Lactose was determined by the method of Acton (1977) and ashes were measured after incineration at $550^{\circ} \mathrm{C}$ during $5 \mathrm{~h}$. Calcium content was determined by atomic absorption spectrometry (Brulé et al, 1974) and phosphorus content by the IDF (International Dairy Federation) spectrophotometric method (1982).

Other parameters were also determined on the powder: the solubility index (SI), as described by FIL-IDF (1988); the aerated bulk density (ABD); the dispersibility index (DI) and the wettability index (WI), all 3 according to Niro Atomizer methods, respectively, $n^{\circ} A 2 a, n^{\circ} A 6 c$ and $n^{\circ} A 5 a$ (1978). Granulometry profile was determined from sieve analysis using an Alpine apparatus A 200 LS (Evry, France). Water activity $\left(\mathrm{a}_{\mathrm{w}}\right)$ was measured at $25^{\circ} \mathrm{C}$ (constant temperature) on a water activity meter Novasina RTD 33TH-2 (Pfäffikon, Switzerland). Confidence limits for these analyses were: SI, $0.5 \% ; \mathrm{ABD},+/-30 \mathrm{~kg} \mathrm{~m}^{-3} ; \mathrm{DI}, 0.5 \%$; WI, $1.5 \mathrm{~s} ; \mathrm{a}_{\mathrm{w}}, 0.5 \%$.

Microbiological counts were carried out on agar $\left(3 \mathrm{~d}\right.$ at $30^{\circ} \mathrm{C}$ or $2 \mathrm{~d}$ at $\left.55^{\circ} \mathrm{C}\right)$ for total counts, on violet red bile agar $\left(30^{\circ} \mathrm{C}, 1\right.$ d) for coliform bacteria enumeration and on meat liver SR agar $\left(37^{\circ} \mathrm{C}, 2 \mathrm{~d}\right)$ for sulfite-reducing Clostridium spores enumeration.

The powder was packed into polystyrene boxes ( $0.4 \mathrm{~mm}$ thickness) and stored at $20-25^{\circ} \mathrm{C}$ 
(approximately $60 \%$ relative humidity). After 1,2 and 3-month storage, a box was opened and samples were quickly deducted. The box was then closed again. Polystyrene material (permeable to water vapor) was specially chosen in order to estimate the effect of a rehydration of the mare's milk powder on its chemical and physical qualities.

\section{RESULTS AND DISCUSSION}

The powder was obtained from 500 I of mare's milk, that led to $40 \mathrm{~kg}$ of mare's milk powder. Whole milk contained $11.5 \mathrm{~g} \mathrm{~kg}^{-1}$ fat, which was not fully separated by the centrifuge since a residual level of $2.0 \mathrm{~g}$ $\mathrm{kg}^{-1}$ of fat was determined in defatted milk. Other constituents in defatted milk, evaporated milk and powder are listed in table I. Total nitrogen matter (TNM: TN $\times 6.38$ ) concentration in mare's milk $\left(16.8 \mathrm{~g} \mathrm{~kg}^{-1}\right)$ as well as ashes content $\left(2.63 \mathrm{~g} \mathrm{~kg}^{-1}\right)$ were lower than in cow's milk. TNM was constituted mainly by the NCN fraction $(10.4 \mathrm{~g}$ $\mathrm{kg}^{-1}$ ) which thus amounted to $62 \%$ TNM, the residual part of TNM being the casein fraction, $6.4 \mathrm{~g} \mathrm{~kg}^{-1}$, much lower than in cow's milk. On the contrary, a higher level of lactose was found $\left(68.9 \mathrm{~g} \mathrm{~kg}^{-1}\right)$, which led to a total solid level of $88.7 \mathrm{~g} \mathrm{~kg}^{-1}$, similar to that of cow's milk. These results agreed with the data of Doreau (1991). In the evaporated milk, TS was $362.1 \mathrm{~g} \mathrm{~kg}^{-1}$, ie increased by a factor $\times 4.08$ compared to the content of the milk. This factor results from the capacity of the vacuum evaporation pilot plant to concentrate at low heat treatment. The composition of the powder, reported in table I, shows a TS of $975.8 \mathrm{~g}$ $\mathrm{kg}^{-1}$ ie a $2.4 \%$ moisture level, which is low in comparison to cow's milk average values ( 4 to $5 \%$ ), but the high proportion of lactose in mare's milk required to spray dry with a high outlet temperature $\left(100^{\circ} \mathrm{C}\right)$ (Masters, 1991). This leads to higher manufacture costs, but is not a technical problem. Other constituents in TS are in the same relative proportions as in evaporated milk. The results in table I make it possible to calculate the SWPi in milk (0.48), in evaporated milk $(0.47)$ and in the powder $(0.44)$. Only a small decrease was observed, meaning very little changes in the soluble protein fraction. Thus, little protein denaturation took place during the transformation. The ratios of soluble to total $\mathrm{Ca}$ and $\mathrm{P}$ were also determined. For calcium, it was 0.39 in milk and 0.36 in the powder, and for phosphorus 0.60 in both products. The very low change in the mineral ratios as in the SWPi shows evidence of mild conditions in milk dehydration.

Table I. Chemical analyses of initial mare's milk and of intermediary products in the milk powder preparation $\left(\mathrm{g} \mathrm{kg}^{-1}\right)$.

Composition chimique des différents produits obtenus pour la préparation de poudre de lait de jument $\left(\mathrm{g} \mathrm{kg}^{-1}\right)$.

\section{TS Ashes Lactose TNM NCN NPN Ca $\quad P$}

\begin{tabular}{lrrrrrrrr} 
Defatted milk & 88.7 & 2.63 & 68.9 & 16.8 & 10.4 & 2.4 & 0.49 & 0.36 \\
Evaporated milk & 362.1 & 10.36 & 296.4 & 67.9 & 41.0 & 9.3 & 1.98 & 1.47 \\
\hline Powder & 975.8 & 29.33 & 791.4 & 184.7 & 108.5 & 26.6 & 5.42 & 4.02
\end{tabular}

TS: total solids/matière sèche; TNM: total nitrogen matter/matière azotée totale; NCN: noncasein nitrogen/azote non caséinique; NPN: nonprotein nitrogen/azote non protéinique. 
Application of heat treatments modified bacterial counts. Total mesophilic flora was $460 \mathrm{cfu} \mathrm{ml}^{-1}$ in milk (table II) and $840 \mathrm{cfu}$ $\mathrm{ml}^{-1}$ in evaporated milk, corresponding to a destruction of $60 \%$ of microflora. On the other hand, total flora, at $30^{\circ} \mathrm{C}$, in the powder was $400 \mathrm{cfu} \mathrm{g}^{-1}$, a value which can be compared to the initial flora in milk calculated for $1 \mathrm{~g}$ of TS, ie $5200 \mathrm{cfu} \mathrm{g}^{-1}$. Flora in the powder is thus 13-fold lower than in milk, corresponding to a destruction of $94 \%$ of microflora. The final total count was lower than the limiting value for "high quality cow's milk powder" ie $<50000$ total flora cfu $\mathrm{g}^{-1}$ (Amariglio, 1986).

Granulometry profile is shown in figure 1. Particle size distribution with only $7 \%$ of the material $<100 \mu \mathrm{m}$ and $90 \%$ comprised between 100 and $315 \mu \mathrm{m}$ was observed. Small particles $(<80 \mu \mathrm{m})$ were, however, probably formed during spray drying because, due to its low protein content (Whitnah, 1962), the evaporated milk had low TS and, consequently, low viscosity (Morand, 1975; Masters, 1991). However, the small particles reincorporation into the atomization zone was used in the spray drying procedure. Thus, the powder was agglomerated by this procedure, which permitted electrostatic agglomeration of small particles and droplets. Results concerning other physical characteristics of the pow- der are shown in table III. The high value of the solubility index ( $\mathrm{SI}>99.5 \%$ ) and that of the dispersibility index ( $\mathrm{DI}=97.2 \%$ ) as well as the low value of the wettability index (WI $=3.5 \mathrm{~s}$ ) of the powder, demonstrate that it had the characteristics of an instant powder. Moreover, its low water activity $\left(a_{w}\right.$ $=0.18$ ) would allow storage with low lactose crystallization (Ozimek et al, 1992), low hydroxymethylfurfural development and low microorganism increase (Labuza, 1975).

After 3-month storage of mare's milk powder, physical properties were modified or not. The solubility remained unchanged (>99.5\%) as well as the dispersibility $(97 \%$, standard deviation $=0.5$ ). On the contrary, a regular increase in water content $v s$ time was observed, which nevertheless remained $<5 \%$ after 3 months (table III), ie inferior to the limit assigned to instant cow's milk powder (Amariglio, 1986). Moreover, we have observed an increase in the wettability index (WI) and the water activity $\left(\mathrm{a}_{\mathrm{w}}\right)$, with time. The increase in WI was presumably the consequence of the increase in moisture which produced a superficial hydrated layer on the powder grain surface. Such a layer could constitute an impermeable barrier for penetration of water in the conditions applied during the wettability test, while no effect was observed in the conditions of determi-

Table II. Bacterial counts in mare's milk, evaporated milk and powder (cfu: colony-forming unit). Énumération bactérienne dans le lait, dans le lait concentré et dans la poudre (ufc).

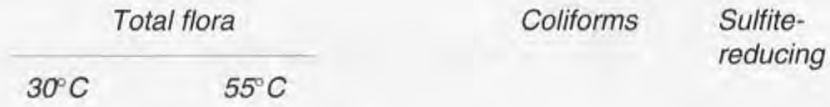

\begin{tabular}{|c|c|c|c|c|}
\hline Defatted milk $\left(\mathrm{ml}^{-1}\right)$ & 460 & $<10$ & 12 & $<10$ \\
\hline Evaporated milk $\left(\mathrm{ml}^{-1}\right)$ & 840 & $<10$ & $<10$ & $<10$ \\
\hline Powder $\left(g^{-1}\right)$ & 400 & $<10$ & $<10$ & $<10$ \\
\hline
\end{tabular}


nation of the solubility index. The increase in $\mathrm{a}_{\mathrm{w}}$ is an indicator of inappropriate storage conditions of the mare's milk powder. The polystyrene container is known as permeable to water vapor. Due to its hygroscop- icity, the powder should have been stored in a water vapour impermeable container, for example, polyethylene-made, or at low temperature and low relative humidity (De Vilder, 1982).

Table III. Physical index determined in mare's milk fresh powder. Evolution on storage of physical indexes and water content of mare's milk powder.

Propriétés physiques de la poudre de lait de jument. Évolution des indices physiques et de la teneur en eau de la poudre au cours de la conservation.

$\begin{array}{lllllll}\begin{array}{l}\text { Length } \\ \text { of storage } \\ \text { (month) }\end{array} & A B D & S I & D I & \text { WI } & a_{w} & \text { Water } \\ \left(\mathrm{kg} \mathrm{m}^{-3}\right) & (\%) & (\%) & \text { (s) } & & \text { (\%) }\end{array}$

$\begin{array}{lllllll}\begin{array}{l}\text { Fresh powder } \\ 0\end{array} & 590 & >99.5 & 97.1 & 3.5 & 0.18 & 2.4 \\ 1 & - & >99.5 & 96.5 & 5.0 & 0.24 & 3.2 \\ 2 & - & >99.5 & 97.6 & 5.0 & 0.28 & 4.4 \\ 3 & - & >99.5 & 97.2 & 7.0 & 0.28 & 4.1\end{array}$

ABD: aerated bulk density/masse volumique apparente; SI: solubility index/indice de solubilité; DI: dispersibility index/indice de dispersibilité; WI: wettability index/indice de mouillabilité; $\mathrm{a}_{\mathrm{w}}$ : water activity/activité de l'eau; water: moisture/humidité.

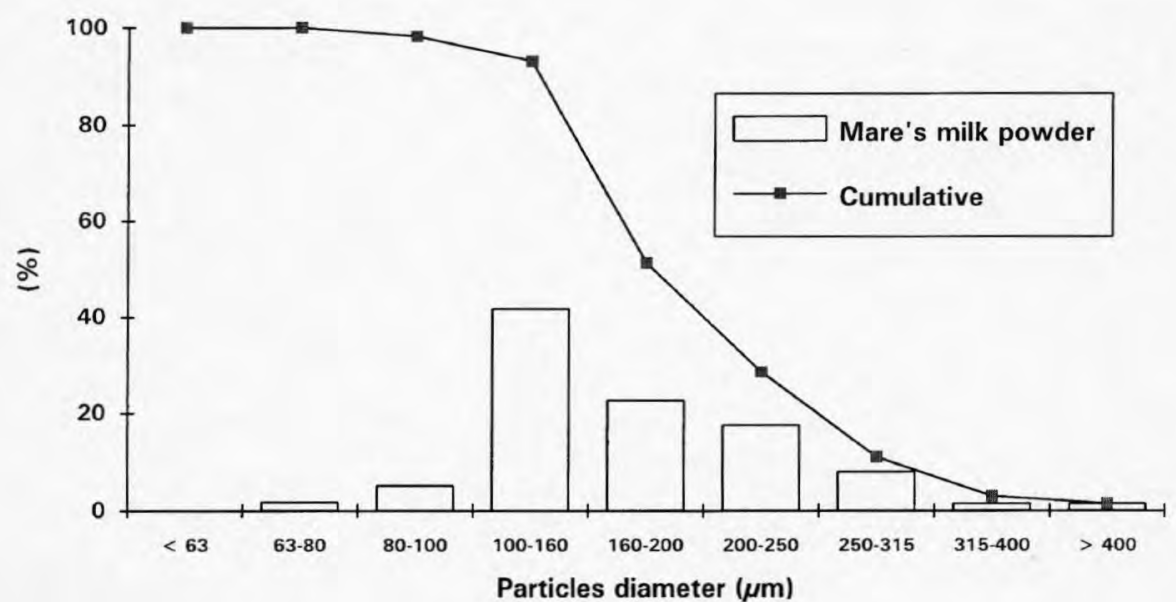

Fig 1. Granulometric profile of mare's milk powder.

Profil granulométrique de la poudre de lait de jument. 


\section{REFERENCES}

Acton $\mathrm{GH}$ (1977) The determination of lactose in cheese. Aust J Dairy Technol 32, 111

Amariglio S (1986) Contrôle de la qualité des produits laitiers. Analyses physiques et chimiques. AFNOR, ITSV, Paris, $3^{e}$ edn, $439-445$

Baudoin N (1990) Situation de l'élevage équin en France. Compte-rendu de la session FEZ de la commission de production chevaline, Toulouse, 11 juillet, 1-11

Brulé G, Maubois JL, Fauquant J (1974) Étude de la teneur en éléments minéraux des produits obtenus lors de l'ultrafiltration du lait sur membrane. Lait 54, 600-615

De Vilder J (1982) Altérations en cours de conservation des caractéristiques du lait en poudre. Rev Agric 35, 2051-2064

Doreau M (1991) Le lait de jument. INRA Prod Anim 4 , 297-302

FIL-IDF (1982) Détermination de la teneur en phosphore total dans les fromages. Standard $n^{\circ} 33 B$

FIL-IDF (1988) Détermination de l'indice d'insolubilité. Standard $n^{\circ} 129 A$

Labuza TP (1975) Sorption phenomena in foods: theoretical and practical aspects. In: Theory determination and control of physical properties of food materials (CK Rha, ed) Reidel, Dordrecht, Netherlands, 197

Langlois B, Rossier E, Jolivet G, Coléou J, Martin-Rosset W (1994) 20 années de recherche sur le cheval : défis et stratégies pour l'avenir. Equ'idée 15, 39-53

Le Du P (1986) Mechanical milking of mares. Paper presented at the 37th Animal Meeting of the European Association for Animal Production, Budapest, Hungary, 1-4 September

Masters K (1991) Spray drying. 5th edn. Longman Scientific and Technical and John Wiley and Sons Inc, Essex, UK, 232-249, 499-511

Morand A (1975) Le séchage par pulvérisation. Journées CPCIA, 4-14

Niro Atomizer (1978) Méthodes d'analyses des produits laitiers déshydratés. 4th edn, Copenhague, Denmark

Ozimek L, Switka J, Wolfe F (1992) Water sorption properties of ultrafiltration retentate skim milk powders. Milchwissenschaft 47, 752-754

Rowland SJ (1938) The determination of the nitrogen distribution in milk. J Dairy Res $9,42-46$

Whitnah $\mathrm{CH}$ (1962) The viscosity of milk in relation to the concentration of major constituents and to seasonal differences in the voluminosity of complexes of sedimentable nitrogen. J Agric Food Chem 10, 295-296 